\title{
Adrenocortical carcinoma with pure aldosterone hypersecretion
}

INSERM

\section{Source}

INSERM. (1999). Orphanet: an online rare disease and orphan drug data base.

Adrenocortical carcinoma with pure aldosterone hypersecretion. ORPHA:231625

Adrenocortical carcinoma with pure aldosterone hypersecretion (pure APAC) is a very rare surgically-correctable form of primary aldosteronism (PA; see this term) due to an aldosterone-secreting adrenal malignancy. 